\title{
Soil Fertility and Salinity Status of Muzaffargarh District, Punjab Pakistan
}

\author{
Zeeshan Akram ${ }^{1, *}$, Sajid Hussain ${ }^{1}$, Mudassir Mansoor ${ }^{1}$, Muhammad Afzal ${ }^{2}$, Adil Waqar ${ }^{2}$ \\ Imran Shabbir ${ }^{2}$ \\ ${ }^{1}$ Soil and Water Testing Laboratory, Cane Development Cell \\ ${ }^{2}$ Fatima Sugar Mills, Muzaffargarh, Punjab, Pakistan \\ *Corresponding Author: uafshani430@gmail.com
}

Copyright (C) 2014 Horizon Research Publishing All rights reserved.

\begin{abstract}
The main objective of this paper is to check the soil fertility and salinity status. For this purpose, a total of 3325 soil samples, collected from all tehsils of Muzffargarh district (from tehsil Muzaffargarh, Jatoi, Kot Addu and Ali Pur), were tested in the Soil and Water Testing Laboratory, Cane Development Cell, Fatima Sugar Mills, Muzaffargarh, Pakistan from 2012 to 2014. Samples were analyzed for soil reaction ( $\mathrm{pH} 1: 10)$, electrical conductivity (EC1:10), soil organic matter (SOM), sodium adsorption ratio (SAR) and plant available phosphorus (Olsen-P). The results revealed that $\mathrm{pH}$ ranged between 8.5-9.0 in 75 percent of the samples while about 95 percent were normal with respect to salinity $(\mathrm{EC}<4 \mathrm{dS} / \mathrm{m})$ and 74 percent were not affected by sodicity (SAR $<15)$. Soils were poor in organic matter $(92$ percent samples had less than 0.80 percent $\mathrm{OM}$ ) and available phosphorus ( 95 percent samples had less than 15 $\mathrm{mg} \mathrm{P} / \mathrm{kg}$ soil).
\end{abstract}

Keywords Soils, Soil Fertility, Salinity, Pakistan

\section{Introduction}

Muzaffargarh is one of the most important districts of Punjab from the agricultural point of view. It is located between $29^{\circ} 6^{\prime}$ to $30^{\circ} 45$ ' $\mathrm{N}$ Latitude and $70^{\circ} 30^{\prime}$ to $71^{\circ} 48^{\prime} \mathrm{E}$ Longitude, in the middle of Pakistan between the two famous rivers of the sub-continent, Chenab and Indus. Muzaffargarh district consists of four tehsils Alipur, Jatoi, Kot Addu and Muzaffargarh. Nearly most of the area of tehsil Alipur and some parts of Muzaffargarh tehsil are flooded every year. The district's towns include Khangarh, Rohillan wali, Shaher Sultan, Rangpur, Gujrat, Budh, Mehmood Kot, Sinawan, Thatta Gurmani, Daira Din Panah, Chowk Sarwar Shaheed, Shah Jamal, Mahrpur, Baseera, Wasanday wali, Jalwala, Pir Amir, BindaIshaq, Ehsan Pur, Bakaini, Seet Pur, Murad Abad, Ghazi Ghaat, Karam Dad Qureshi \& Douna Alipur and Jatoi. Muzaffargarh region has an arid climate with very hot summers and mild winters; it is exposed to some of the most extreme weather condition in the country, with highest temperature recorded at $54^{\circ} \mathrm{C}(129 \mathrm{~F})$ and the lowest temperature at $-1^{\circ} \mathrm{C}\left(30^{\circ} \mathrm{F}\right)$, and an average annual rainfall of about 127 millimeters. The total area of the district of Muzaffargarh is 830 thousand hectares, of which 112.7 thousand hectare is salt affected and 1.17 thousand hectare is water logged (Anonymous 2013). On average 440 thousand hectares can be used for crop production. Wheat, sugarcane and cotton are the main crops grown, rice, jawar, bajra, moong, mash, masoor, ground nuts, maize and oil seeds (rape seeds and sunflower) being grown at a much lower scale. Mangoes, dates, citrus and pomegranate are the main fruits trees grown whereas dates, jaman, pears, phalsa and bananas occupy a limited area (Anonymous 2013).

Soil fertility status varies with nature of the cropping pattern and management practices. In Pakistan, most of the agricultural lands are nutrient deficient (Anonymous 2008 a).Ahmad and Khan (2006) declared that 75-92 percent soils of Pakistan are deficient in organic matter ( $0-1$ percent), 70-95 percent in phosphates and 20-60 percent soils in potash. It has been found that micronutrients; such as zinc, boron and iron are also emerging as deficient nutrient in soils of Pakistan (Anonymous 2008 b).

In spite of the inherent low soil fertility, crop yield can still be increased by $30-50$ percent with the use of balanced fertilization (Anonymous 2006), on the basis of soil tests which is a pre-requisite for applying the right fertilizer at the right dose to optimize productivity. Furrukh et al. (1992) have studied farmers' soil fertility management strategies that are based solely on resources available, namely off counter chemical fertilizers type, land type, cropping pattern, fallowing and cultural practices. This approach however failed to address scientifically the soil fertility problem as it lacked soil testing facilities for an informed decision. The creation of the soil laboratory facility at Fatima Sugar Mills in 2012 has bridged the technological gap that existed in the Muzaffargarh crop production system by providing soil testing services to the community. After 2 years in operation, the objective of this study is to have a stock take of the severity of agricultural soil deficiencies in Muzaffargarh district and to identify the root cause(s) affecting agricultural productivity and thereby to develop sounder fertilization 
practices and amendments that are more adequate to the individual characteristic of farms.

\section{Materials and Methods}

This study was conducted at the Soil and Water Testing Laboratory of the Cane Development Cell, at Fatima Sugar Mills Muzaffargarh Pakistan during the period 2012 to 2014. Composite soil samples from tehsil Muzaffargarh (840), Jatoi (670), Kot Addu (1225) and Ali Pur (590) were collected from $0-15$ and $15-30 \mathrm{~cm}$ depths for crops and vegetables while $0-15,15-30,30-60,60-90$ and $90-120 \mathrm{~cm}$ depths for orchards. Samples were air-dried, ground and passed through a $2 \mathrm{~mm}$ sieve for analysis. Soil reaction $(\mathrm{pH})$ and electrical conductivity (EC) were measured on a 1:10 soil-water suspension using a calibrated $\mathrm{pH}$ meter and $\mathrm{EC}$ meter, respectively (Malik et al.1984). Samples were also analyzed for organic matter by Walkley and Black method (Cottenieet al. 1979), for exchangeable sodium, potassium, calcium and magnesium extracted in $1 \mathrm{M}$ ammonium acetate $\mathrm{pH} 7.0$ and for available phosphorous extracted with $0.5 \mathrm{M}$ $\mathrm{NaHCO}_{3} \mathrm{pH} 8.5$ followed by colorimetry (Watanabe et al. 1965). The sodium adsorption ratio and CEC as the sum of bases were computed. To compute the total salt index, the electrical conductivity $1: 10$ is converted to ECe by multiplying with the factor Saturation percentage/100 as described by US Salinity Lab. Staff.(Anonymous 1954).

The soil test values were interpreted using the soil evaluation indices proposed by Abrol et al. (1988) for salinity and by Malik et al. (1984) for nutrient status, which are summarized in Table 1:

Table 1. Criteria of parameters used for classification:

(a) Soil Salinity and Sodicity

\begin{tabular}{cccc}
\hline Status & $\mathbf{p H}$ & $\mathbf{E C}(\mathbf{d S} / \mathbf{m})$ & SAR \\
\hline Normal (Salt free) & $<7.5$ & $0-2$ & $<15$ \\
Very Slightly Saline & $<7.5$ & $2-4$ & $<15$ \\
Slightly Saline & $<7.5$ & $4-8$ & $<15$ \\
Moderately Saline & $<8.0$ & $8-13$ & $<15$ \\
Strongly Saline & $<8.5$ & $>16$ & $<15$ \\
& & & \\
Saline-Sodic & $>8.5$ & $<4$ & $\geq 15$ \\
Sodic & $>8.5$ & $\geq 4$ & $\geq 15$ \\
\hline
\end{tabular}

(b) Nutrient Status

\begin{tabular}{|ccc|}
\hline Status & Organic matter (\%) & Olsen P (mg/kg soil) \\
Poor & $<0.80$ & $0-8$ \\
& & \\
Satisfactory & $0.81-1.29$ & $8-15$ \\
& & $>15$ \\
\hline Adequate & $>1.29$ & \\
\hline
\end{tabular}




\section{Results and Discussion}

\section{Dissolved salts (electrical conductivity)}

Excessive amount of dissolved salts in soil solutions causes hindrance in normal nutrient uptake process either by imbalance of ions uptake, antagonistic effect between nutrients or excessive osmotic potentials of soil solution and or a combination of the three effects (Obaidur Rahman et al. 2010). The soil analysis data showed that 94 percent of the samples analyzed in district Muzaffargarh were not saline $(\mathrm{EC}<4 \mathrm{dS} / \mathrm{m})$ and that 74 percent were not sodic $(<15)$. (Table 2). This trend cuts across the different tehsils except for soil sodicity where it appears to be more prevalent at Ali Pur and Jatoi. It is worth noting that, although salinity was not as serious as expected, the high proportion $(>50 \%)$ in soil having slight to higher sodicity appears to impact most on soil low productivity. Therefore under this condition classical mitigating measures, such as the application of gypsum, can contribute significantly to improve the soil production potential (Suriyan et al. 2011). Regarding the range of EC (Table 3$)$, the minimum value $(0.47 \mathrm{dS} / \mathrm{m})$ was observed in tehsil Kot Addu while the maximum value ( $18.05 \mathrm{dS} / \mathrm{m})$ was noticed in tehsil Muzaffargarh during the year 2012-14. However, higher EC was also observed in tehsil Jatoi (14.50 dS/m) and Kot Addu (17.90 dS/m). Ali Pur tehsil had dissolved salts ranging from $0.60 \mathrm{dS} / \mathrm{m}$ to $14.27 \mathrm{dS} / \mathrm{m}$. The reason for high accumulation of salts in some places is due to water logging and application of poor quality irrigation water containing soluble salts. (Ayers, $R$. S. and D.W. Westcot 1985). The practice of irrigating the field with high EC-water (bore-hole) constitutes a limitation to agricultural activity. Yet the low proportion $(<10 \%)$ of the salinity inflicted soils at Muzaffargarh indicated the low ionic exchange properties of the soils attributable to the sandy texture that is common to the soils in this region. This in turn indicates the poor ability of the soil to retain plant nutrient for crop production. This should be considered in the fertilization practices whereby residual values of fertilizers could not be reckoned with and the fate of excessive doses of fertilizer is lost to ground water.

\section{Soil alkalinity}

Twenty six percent of the soils had a $\mathrm{pH} 7.5-8.5$, that are suitable for agriculture. Seventy-four percent of soils had $\mathrm{pH}>$ 8.5 which are limiting to agricultural production. These soils are calcareous and the level of exchangeable sodium is often high. Alkalinity problem in soils is due to the indigenous calcareous parent material with typical low organic matter content (Brady, N.C. and R.R. Weil. 2005). Resorting to high doses (as high as 10 tons per acre) of gypsum amendment is not sufficient to reclaim soils having high $\mathrm{pH}(>8.5)$ and high sodium content, thus acid and sulphur additions are often warranted (Sherry Combs, 2007). The reclamation can be so expensive that it might not be justifiable. These problematic soils are encountered mostly in areas prone to water logging conditions since as mentioned earlier sandy soils normally have low retention capacity for free ions. Indeed these are mostly common in fields with shallow water table induced by seepage water losses from feeder canals or by upward movement of water by capillary from the two adjacent sub-continental rivers.

\section{Organic matter}

Organic matter has a vital role in agricultural soil. It supplies plant nutrient, improve the soil structure, improve water infiltration and retention, feeds soil microflora and fauna, and the retention and cycling of applied fertilizer (Johnston A.E. 2007). Thus it contributes positively to higher crop yields. Over 95 percent of the soils were deficient in organic matter content leaving a meagre fraction of 4.5 percent that had satisfactory levels (Table 2). The low organic matter content is due to an increased rate of decomposition triggered by the high temperature exceeding $45^{\circ} \mathrm{C}$ in summer. Burning or fodder use of the plant material remaining after harvest leave very little to replenish the soil in organic matter (Azam et al. 2001). Growers seldom use farmyard manure and green manuring is rarely done due to subsistence farming leaving little scope for such practice. Low productivity also leads to reduced crop leftover that can be returned to the soil. There is therefore a strong need to adopt measures that can improve the soil organic matter status; otherwise desertification is looming at the horizon for many of these soils. (Sieglinde S. Snapp. 2011)

\section{Plant available phosphorus}

The results (Table 2) showed that phosphorus availability to plants was satisfactory (above 90 percent) irrespective of the tehsil. 2 to 9 percent of the soils had values above the benchmark of $15 \mathrm{mg} \mathrm{P} / \mathrm{kg}$ (Table 3).Poor levels of plant available phosphorus result firstly from its fixation in calcareous soil due to the high levels of calcium carbonate(Ray von Wandruszka, 2006) and secondly to the recurrent application of phosphatic fertilizers below the recommended rates. Current agronomic recommendation rate for NPK is 1.0:0.6:0.4 but presently it is stagnant at 1.0:0.3:0.01(Anonymous 2008 b).

\section{Acknowledgments}

The work presented in this manuscript was accomplished under the sympathetic attitude, fatherly behavior, animate direction, observant pursuit, scholarly criticism, cheering perspective and enlightened supervision of Jean Pierre Paul, Soil Chemist, Mauritius Sugar Industry Research Institute. I am grateful to his ever-inspiring guidance, keen interest, scholarly comments and constructive suggestions throughout the course of my studies and research paper completion.

I deem it an utmost pleasure in expressing my gratitude with the profound thanks to Danny N.I. Dabeesing, Head of Department, Cane Development Cell and Zulfqar Waseem 
Malik, General Manager, Cane Procurement Department, for providing me the strategic command at every step. I extend deep emotions of appreciation, gratitude and indebtedness for their valuable guidance. Friends are the comrades of the battle, the battle to generate knowledge, sift myths and facts and to remove ambiguity. They were co-sharer of my struggle and my work. I express my thankful feeling for all my friends. 
Table 2. Results of Soil samples analyzed Tehsilwise (in \%age)

\begin{tabular}{|c|c|c|c|c|c|c|c|c|c|c|c|c|c|c|c|c|c|}
\hline \multirow[b]{2}{*}{ 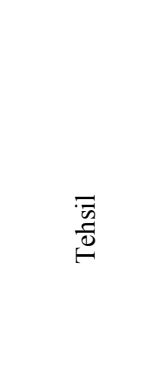 } & \multicolumn{5}{|c|}{ Dissolved Salts } & \multicolumn{3}{|c|}{$\mathrm{pH}$} & \multicolumn{3}{|c|}{ Organic Matter } & \multicolumn{3}{|c|}{ Olsen-P(Phosphorous) } & \multicolumn{3}{|c|}{ SAR } \\
\hline & $\begin{array}{l}\overline{\text { J }} \\
\text { ह0 } \\
\text { z }\end{array}$ & 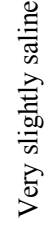 & 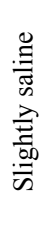 & 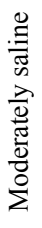 & 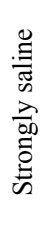 & $\stackrel{n}{\tilde{v}}$ & $\begin{array}{l}n \\
\infty \\
1 \\
n \\
r\end{array}$ & $\stackrel{n}{\infty}$ & ¿ّ & 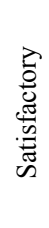 & 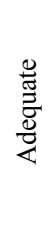 & 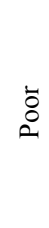 & 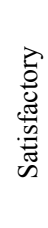 & 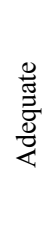 & $\begin{array}{l}\bar{Z} \\
\tilde{E} \\
z\end{array}$ & 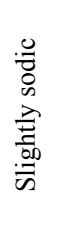 & \begin{tabular}{l}
0 \\
\hdashline \\
\hdashline
\end{tabular} \\
\hline Muzaffargarh & 84 & 13 & 2 & 1 & 0 & 0 & 14 & 86 & 93 & 7 & 0 & 4 & 94 & 2 & 47 & 29 & 24 \\
\hline Kot Addu & 72 & 17 & 5 & 6 & 0 & 0 & 21 & 79 & 94 & 6 & 0 & 4 & 93 & 3 & 45 & 30 & 25 \\
\hline Ali Pur & 78 & 12 & 6 & 4 & 0 & 0 & 42 & 58 & 98 & 2 & 0 & 2 & 92 & 6 & 38 & 36 & 26 \\
\hline Jatoi & 76 & 14 & 6 & 4 & 0 & 0 & 26 & 74 & 97 & 3 & 0 & 1 & 90 & 9 & 45 & 33 & 22 \\
\hline
\end{tabular}

Table 3. Ranges of different soil parameters (Tehsilwise)

\begin{tabular}{|c|c|c|c|c|c|c|c|c|c|c|c|c|c|c|c|}
\hline \multirow{2}{*}{ Tehsils } & \multicolumn{3}{|c|}{$\mathrm{pH}$} & \multicolumn{3}{|c|}{$\mathrm{EC}(\mathrm{dS} / \mathrm{m})$} & \multicolumn{3}{|c|}{ Olsen Phosphorous (mg/kg) } & \multicolumn{3}{|c|}{ Organic Matter (\%) } & \multicolumn{3}{|c|}{ Sodium Adsorption ratio } \\
\hline & Min. & Max. & S.D & Min. & Max. & S.D & Min. & Max. & S.D & Min. & Max. & S.D & Min. & Max. & S.D \\
\hline Muzaffargarh & 8.06 & 9.53 & 0.21 & 0.82 & 18.05 & 1.68 & 7 & 21 & 1.89 & 0.35 & 0.92 & 0.11 & 2 & 50 & 8.00 \\
\hline Kot Addu & 7.82 & 10.24 & 0.26 & 0.47 & 17.90 & 1.50 & 6 & 22 & 1.94 & 0.24 & 0.96 & 0.12 & 2 & 54 & 7.30 \\
\hline Ali Pur & 8.01 & 9.18 & 0.27 & 0.60 & 14.27 & 1.95 & 7 & 20 & 2.14 & 0.40 & 0.84 & 0.09 & 2 & 45 & 8.43 \\
\hline Jatoi & 7.90 & 9.03 & 0.25 & 0.61 & 14.50 & 1.71 & 7 & 19 & 2.09 & 0.34 & 0.84 & 0.11 & 2 & 50 & 8.22 \\
\hline
\end{tabular}




\section{Recommendations}

- Soil organic matter level and soil fertility status may be increased by green manuring (sesbania, guar, etc.) once in three years.

- Inorganic fertilizers (NPK) should be applied in balanced form according to soil test values and their use efficiency can be increased by band placement for row-sown crops.

\section{Recommendations for district Muzaffargarh on the basis of analysis results are given below}

\begin{tabular}{|c|c|c|c|c|}
\hline \multicolumn{5}{|c|}{ Nutrients recommendations for different crops. } \\
\hline \multirow{2}{*}{ Crops } & \multirow{2}{*}{ Fertility status } & \multicolumn{3}{|c|}{ Fertilizer rate $(\mathrm{kg} / \mathrm{acre})$} \\
\hline & & $\mathrm{N}$ & $\mathrm{P}$ & $\mathrm{K}$ \\
\hline Sugar Cane & Poor & 78 & 30 & 50 \\
\hline Sugar Cane & Medium & 58 & 26 & 37 \\
\hline Wheat & Poor & 52 & 46 & 25 \\
\hline Wheat & Medium & 42 & 34 & 25 \\
\hline BT Cotton & Poor & 155 & 65 & 50 \\
\hline BT Cotton & Medium & 140 & 52 & 50 \\
\hline Non BT Cottn & Poor & 72 & 35 & 25 \\
\hline Non BT Cottn & Medium & 60 & 35 & 25 \\
\hline Rice & Poor & 58 & 33 & 25 \\
\hline Rice & Medium & 48 & 25 & 25 \\
\hline Maize (Hybrid) & Poor & 80 & 60 & 37 \\
\hline Maize (Hybrid) & Medium & 65 & 46 & 37 \\
\hline
\end{tabular}

Source: Soil Fertility, Survey and Soil Testing Institute, Punjab, Lahore.

\section{(Annexure-I)}

Nutrient deficiency extent in soils and fertilizer use efficiency

\begin{tabular}{ccc}
\hline Nutrient & Percent soil deficiency & Percent fertilizer use efficiency \\
\hline & & \\
Nitrogen & 100 & $40-60$ \\
Phosphorous & 90 & $15-20$ \\
Potassium & 50 & $75-85$ \\
Zinc & 70 & $4-5$ \\
& & $11-15$ \\
Iron & 70 & $6-8$ \\
Boron & 50 & $3-5$ \\
Copper & 15 & \\
\hline
\end{tabular}


Factors contributing to low fertilizer use efficiency

\begin{tabular}{|c|c|c|}
\hline \multicolumn{2}{|c|}{ S.No. } & \multicolumn{2}{c|}{$\begin{array}{c}\text { Percent contribution to low fertilizer use } \\
\text { efficiency }\end{array}$} \\
\hline 1 & Poor seed bed preparation & $10-25$ \\
\hline 2 & Improper seeding & $5-20$ \\
\hline 3 & Delayed sowing & $20-40$ \\
\hline 4 & Inappropriate variety & $20-40$ \\
\hline 5 & Inadequate plant population & $10-25$ \\
\hline 6 & Improper fertilizer placement & $5-10$ \\
\hline 7 & Imbalanced fertilizer use & $20-50$ \\
\hline 8 & Inadequate irrigation & $10-20$ \\
\hline 9 & Weed infestation & $15-50$ \\
\hline 10 & Insect attack & $5-50$ \\
\hline
\end{tabular}

Source: Anonymous, (2008c). Pakistan Fertilizer Related Statistics. NFDC

\section{REFERENCES}

[1] Abrol P.I, Jai Singh Pal Yadav, F. I. Massoud 1988. Salt-affected Soils and Their Management. Food and Agriculture Organization of the United Nation Rome. Soils bulletin 39, Pp. No. 13-25.

[2] Ahmad, N. and A. A. Khan. 2006. Nutrient management for sustainable agriculture in Pakistan. In: Poster Session. IFA Conference "Optimizing Resource Use Efficiency for Sustainable Intensification of Agriculture”. Feb. 27-March 4, 2006; Kunming, China.

[3] Anonymous 1954. Diagnosis and Improvement of Saline and Alkali Soils. USD A Handbook No. 60, U. S. Salinity Lab. Staff. Washington, DC, USA. p. 16-17.

[4] Anonymous 2006. Balanced fertilization through phosphate promotion at farm level; Impact on crop production. Final Report on three phases of trials (1987-2005). NFDC, Islamabad.

[5] Anonymous 2008 (a). Economic Survey of Pakistan. Govt. of Pakistan, Islamabad.

[6] Anonymous 2008 (b). Fertilizer use efficiency and crop productivity: where we stand and what should be done (Panel discussion). Proc. Symp. "Balanced Fertilizer Use: Impact on Crop Production" Oct. 30-31, 2006. NFDC, Islamabad.

[7] Anonymous 2008 (c). Pakistan Fertilizer Related Statistics. Review Report 01/2008 Statistical Bulletin. NFDC, Islamabad

[8] Anonymous 2013. Punjab Development Statistics. Govt. of the Punjab, Lahore.

[9] Ayers, R.S. and D.W. Westcot. 1985. Water quality for agriculture. Food and Agricultural Organization (FAO) of the United Nations. FAO Irrigation and Drainage Paper 29
[10] Azam, F., M. M Iqbal, C. Inayatullah and K. A. Malik. 2001. Technologies for sustainable agriculture. Nuclear Institute for Agriculture and Biology, Faisalabad

[11] Brady, N.C. and R.R. Weil. 2005. The Nature and properties of soil (Thirteenth Edition) Macmillan Publishing Co. New York.

[12] Cottenie, A. M., G. Velgis and I. Kicken. 1979. Analytical Method for Plant and Soils. Laboratory of Analytical and Agro-chemistry. State University, Belgium.

[13] Furrukh, A. M., I. Saeed, M. Dawson and Z. Ahmad. 1992. Farmers rationale for fertility, moisture management in Punjab (Pakistan). J. Agric. Res. 30 (3): 371-379.

[14] Johnston A.E. 2007. Soil organic matter, effects on soil and crop. Soil use and management. Volume 2. Issue 3. Pp.No. 97-105.

[15] Malik, D. M., M. A. Khan and T. A. Chaudhry. 1984. Analysis Manual for Soils, Plants and Waters. Rapid Soil Fertility Survey and Soil Testing Institute, Lahore, Pakistan.

[16] Obaidur Rahmanet 2010. Soil fertility and salinity status of Attock District. J. Agric. Res. 48 (4).

[17] Ray Von Wandruszka, 2006. Phosphorus retention in calcareous soils and the effect of organic matter on its mobility. Geo Chemical Transaction, Department of Chemistry, University of Idaho, Moscow.

[18] Sherry Combs 2007.Reducing Soil pH. University of Wisconsin-Extension

[19] Sieglinde S. Snapp. 2011. Advanced soil organic matter management. Extension Bulletin E-3137. Michigan State University

[20] Suriyanet al. 2011. Remediation of salt-affected soil by gypsum and farmyard manure. Australian Journal of crop sciences 5(4) : 458-465

[21] Watanabe, F. S. and S. R. Olsen. 1965. Test of an ascorbic 
acid method for determining phosphorus in water and sodium bicarbonate extract from soils. Soil Sci. Soc. Amer. Pro. 29:

405-410. 